\title{
Editorial
}

\section{RECENT ADVANCES IN NEUROLOGY OF THE PERIPHERAL NERVES}

The late war provided an inexhaustible fund of experience in neuropathology. The study of the material afforded by the cases of injuries to the peripheral nerves has been especially fruitful. The research in the neurologic departments of the various armies has demonstrated that anatomic and physiologic ideas current prior to the war were inadequate to explain many of the phenomena associated with injuries to the peripheral nerves.

Compared with the neurologists of the other armies, those of the American army were afforded but a meager opportunity for the study of neuropathology. The few months in which we were actively engaged in warfare, with the necessity for rapid and efficient medical function, did not permit the fullest organization of neurologic units for consistent research of injuries to the nervous system in the cases observed in France. On their return to the United States, the patients with peripheral nerve injuries were assembled in a number of special hospitals where they were closely studied and, when necessary, treated surgically.

The attempts to establish syndromes to differentiate cases of anatomic interruption, compression, irritation, dissociation and recovery, chiefly by $M$. and Mme. Déjerine and M. Mouzon, ${ }^{1}$ have not resulted in any definite conclusions. The American school agrees with many of the French workers that, clinically, anatomic and physiologic interruptions are indistinguishable. Valuable indications of severe lesions have, however, been established (Meige, ${ }^{2}$ Pittres, ${ }^{3}$ AthanassioBenisty ${ }^{4}$ ).

Research in the fields of motion and sensation has explained certain heretofore confusing observations. Supplementary motility was recognized by Swan in 1834. Much of the knowledge concerning this

1. Déjerine, J. J.: Déjerine, Mme., and Mouzon, J. Presse méd., May 10, July 8 and Aug. 30, 1915.

2. Meige: Rev. Neurol. 23, April-May, 1916.

3. Pitres: Rev. Neurol. 23:477 (April) 1916.

4. Athanassio-Benisty: Clinical Forms of Nerve Lesions and the Treatment and Repair of Nerve Lesions, Military Medical Manual,. London, 1918. 
type of movement, which is often responsible for a failure of recognition of the severity of a lesjon, was furnished by Duchenne, Beevor and Sherren. Since the war, the importance and common occurrence of these movements has been emphasized by Claude, ${ }^{5}$ AthanassioBenisty, and in this country by Wood, ${ }^{6}$ Ingham and Arnett ${ }^{2}$ and Pollock. $^{8}$

In the field of sensation, it is notable in the work of the Allies that, whatever their observations may have been, there is a tendency to concur with the theories of Head. Contributions to sensory studies have been of two types. First, such as detail the sensory distribution of peripheral nerves, notable among which is the work of Stopford, ${ }^{9}$ and in this country, Hamilton ${ }^{10}$ and Grimberg $;^{11}$ second, investigation of the possible existence of separate fibers for epicritic and protopathic sensibilities. These have been studied chiefly in the United States. The problem has been attacked from two angles; first, by Cobb, ${ }^{12}$ who has shown, by employing painful stimuli with low degrees of pressure of known quantity, that the areas of tactile anesthesia and analgesia are coextensive; second, by Pollock, ${ }^{13}$ whose work tends to show that the early and dissociated return of pain sensibility to higher degrees of pressure is not due to an unphysiologically rapid regeneration of protopathic fibers, but to assumption of function of overlapping nerves. A sign of some confirmatory diagnostic value (Tinel ${ }^{14}$ has been added.

In common with other observers, the American neurologists have found electrical reactions to be disappointing as absolute indications of the severity of the lesion. Attention has been directed by the English school to the practical employment of measured shocks from a condenser to determine the degree of injury and regeneration. The importance of coexistence of vascular and joint lesions has been emphasized. The French school has called attention to the occurrence of physiopathic disorders which require differentiation from injuries of the peripheral nerves. Only a negligible number of these so-called

5. Claude: 'Rev. Neurol., April-May, 1916.

6. Wood: Arch. Neurol. \& Psychiat. 2:532 (Nov.) 1919.

7. Ingham and Arnett: Arch. Neurol. \& Psychiat. 3:107 (Feb.) 1920.

8. Pollock: Arch. Neurol. \& Psychiat. 2:518 (Nov.) 1919.

9. Stopford: Anatomy, October, 1918.

10. Hamilton: Arch. Neurol. \& Psychiat. 3:277 (March) 1920.

11. Grimberg: Arch. Neurol. \& Psychiat. 2:338 (Sept.) 1919.

12. Cobb: Arch. Neurol. \& Psychiat. 2:505 (Nov.) 1919.

13. Pollock: Arch. Neurol. \& Psychiat. 2:667 (Dec.) 1919.

14. Tinel: Presse méd. $23: 835$ (Oct. 7) 1915. 
"congealed hands" have been observed by the American neurologists, who agree with Roussy and Lhermitte ${ }^{15}$ that they are functional in character as opposed to the view of Babinski. ${ }^{16}$

One of the most important investigations has been directed to the study of intraneural localization or peripheral nerve topography. The specificity of localization of nerve fasciculi was first emphasized by Stoffel. During the war, Marie, Meige and Gosset ${ }^{17}$ were able to confirm this work, with certain modifications, by intraneural electrization. M. and Mme. Déjerine, ${ }^{18}$ studying partial lesions the locations of which were confirmed by operation, obtained charts of intraneural localizations of a character somewhat varied from the preceding investigators. In this country a notable contribution to this subject appearing in the September issue of the Archives of NeurolOGY has been made by Kraus and Ingham. ${ }^{19}$ Their investigations were a continuation of the work of Marie. They point out that one fact is brought out with certainty, the course of motor fasciculi is a straight one from the point where the nerve has been made up by its contributing segments to the point of offset of the fasciculi as a branch. This work permits conclusions opposed to those of Dustin, ${ }^{20}$ who called attention to the presence of intraneural plexuses between each branch of a nerve, and of Langley and Hashimoto. ${ }^{21}$

Our knowledge of experimental regeneration of nerves has been enriched by the American investigators, Lewis and Kirk ${ }^{22}$ and Huber. ${ }^{23}$ It is definitely established that regeneration of a severed nerve occurs from the outgrowth of the axons of the proximal segment. The work of Huber on direct suture and various forms of transplants. fresh and preserved, has indicated the proper surgical treatment of various peripheral nerve lesions. Lateral implantation and nerve plastics have been discarded. The surgical treatment of these injuries seems to offer a.better prognosis in the hands of American than other operators. Valuable contributions on surgical treatment have already

15. Roussy and Lhermitte: Military Medical Manual, The Psychoneuroses of War. Author: Please give publisher and year.

16. Babinski: Rev. Neurol., April-May, 1916.

17. Marie, Meige and Gosset: Compt. rend. Acade. d. méd., Dec. 28, 1915.

18. Déjerine, J. J., and Déjerine, Mme.: Presse méd., No. 13 (March 2) 1916.

19. Kraus, W. M., and Ingham, S. D.: Electrical Stimulation of Peripheral Nerves Exposed at Operation, J. A. M. A. 74:586 (Feb. 28) 1920.

20. Dustin: L'Ambulance de L'Ocean, 1917.

21. Langley and Hashimoto: Quoted by Kraus and Ingham.

22. Lewis and Kirk: Bull. Johns Hopkins Hosp., February, 1917, p. 71.

23. Huber: Arch. Neurol. \& Psychiat., 1919. Author: Please give volume and page. 
appeared by Stookey, ${ }^{24}$ Dean Lewis, ${ }^{25}$ Frazier, ${ }^{26}$ Spear and Babcock, ${ }^{2 *}$ Price Feiss and Terhune ${ }^{28}$ and Elsberg. ${ }^{29}$ Although sufficient time has not elapsed for definite conclusions to be drawn, a promising outlook is afforded by their reports.

L. J. P.

24. Stookey: Surg., Gynec. \& Obstet. $23: 639$ (Dec.) 1916.

25. Lewis: Surg., Gynec. \& Obstet. 30:528 (May) 1920.

26. Frazier: Ann. Surg. 71:1 (Jan.) 1920.

27. Spear and Babcock: Arch. Neurol. \& Psychiat. 2:253 (Sept.) 1919.

28. Price, Feiss and Terhune: Arch. Neurol. \& Psychiat. 1:547 (May) 1919.

29. Elsberg, C. A.: Technic of Nerve Suture and Nerve Grafting, J. A. M. A., $73: 1422$ (Nov. 8) 1919. 